\title{
History of geriatric medicine: from Hippocrates to Marjory Warren
}

\author{
A Ritch \\ Postgraduate Student, History of Medicine Unit, University of Birmingham and Retired Consultant in Geriatric Medicine, Birmingham, UK
}

\begin{abstract}
It is widely assumed that geriatric medicine was an invention of the twentieth century. However, from the time of Hippocrates, there has been interest in the prolongation of the lifespan, the maintenance of health in old age and agerelated disease patterns. The debate about whether old age was a natural phenomenon or a disease state was not resolved until the nineteenth century. Calls for medicine relating to old age to be recognised as a discrete entity at the time when medical specialisation was developing were disregarded until the second half of the twentieth century. This review discusses the history of the theories of ageing and of disease and the practice of medicine for older people from the classical period up to Marjory Warren's initiative in London in 1935 and the development of geriatrics as a medical specialty.
\end{abstract}

KEYWORDS Geriatrics, old age, gerocomy, medical specialisation

DECLARATION OF INTERESTS No conflicts of interest declared.

\author{
Correspondence to A Ritch \\ 3 Wyvern Road, \\ Sutton Coldfield B74 2PS, UK
}

tel. $+44(0)$ I 2 I 3552819

e-mail aes@ritch.plus.com

\section{INTRODUCTION}

Modern practitioners of geriatric medicine tend to assume that the specialty is a recent development, but an interest in the medicine of old age has existed throughout history. There is disagreement about its establishment however between some American geriatricians, who assert that it was created with the invention of the word 'geriatrics' by lgnatz Nascher in 1909, and British geriatricians who claim its foundation in London in 1935, with the work of Marjory Warren. ${ }^{1-3}$ Several historians of old age take a longer view, but with no less diversity of opinion. Thane for example stated that the study of old age has a very long history linked to concern over health and disease in later life. ${ }^{4}$ Ackerknecht agreed that geriatrics was as 'old as medicine' and 'no invention of the twentieth century'. Stearns, however, placed the birth of geriatrics in the nineteenth century, although he acknowledged that it existed only at the research level with little contact with real people. ${ }^{6}$ Schäfer agrees that there was no specialisation in training, research or clinical practice in geriatric medicine until the nineteenth century. ${ }^{7}$ However, some of the principles of current teaching in geriatric medicine appear in the Hippocratic Corpus; one of its aphorisms states that 'fevers are not so acute in old people'. Indeed, mankind has been interested in the possibilities of extending the individual lifespan from time immemorial, but it was in Classical Greece that the theories of disease and ageing began to be developed.

\section{ANTIQUITY (500 BC-300 AD)}

The debate surrounding ageing and disease began with Hippocrates and focused on the crucial questions of whether old age is a natural or a pathological condition; if it is an illness in its own right; on whether it is unalterable or susceptible to being controlled or attenuated; and on whether diseases occurring in old age are peculiar to older people or common to those of all adult ages. These debates highlighted the difficulties inherent in defining what constituted health or ill-health in old age; the relationship between the ageing process and disease in old age still remains difficult to delineate.? The Hippocratic Corpus proposed that the ageing process resulted from the gradual and progressive loss of heat from the body, which became colder and drier, and so resembled the properties of earth. "In old persons the heat is feeble, and therefore they require little fuel, as it were, to the flame, for it would be extinguished by much [food] ${ }^{.}$This exemplified the view of old age as a time of increased susceptibility and less resistance to disease, mirroring the current concept of ageing as increasing frailty. ${ }^{9}$ An opposing view, mentioned in two places in the Corpus, is that the body becomes moist in old age because of the tendency to external secretion of moisture, as when coughing, but that theory did not gain general acceptance and was later refuted by Galen. The altered picture of disease at an advanced age is recognised by the authors of the Corpus and a number of illnesses associated with old age are described. 
The ideas recorded in the Corpus were the basis of the theory of old age expounded by Aristotle (384-322 BC), who postulated the union of the soul and body, with the heart as the seat of the soul. Heat was thought to be generated in the left side of the heart and to spread from there throughout the body. A finite amount of energy was present at birth and this internal heat or vital spirit was gradually consumed over time, so that little remained in advanced age. Though innate heat could be fortified by various means, it could never be completely restored to its original level.Aristotle recognised that old age brought with it an increased vulnerability to disease processes, when even minor illnesses could have a fatal outcome in a short space of time. In a major review in 1963, Grant described Aristotle's views as 'visionary' and noted that little further progress in terms of explaining the ageing process had been made until the middle of the twentieth century. ${ }^{10}$

Aristotle's idea of ageing as a natural process associated with increased morbidity suggests that it was not looked upon as a disease entity in its own right. However, the Hippocratic Corpus is not explicit in this regard and it has been assumed by some that Hippocrates considered all old people as ill and old age as a disease. ${ }^{7,11}$ Aristotle's view of a natural death, as one where so much warmth had been lost from the body that a minor environmental stress could cause death, but only after a lengthy period of old age, could be interpreted as supporting the theory of old age as an illness. This became a widely held belief throughout the ancient world and it prevailed for many centuries. It is exemplified in Terence's play, Phormio, performed around $\mathrm{I} 6 \mathrm{I} \mathrm{BC}$, when one of the actors says that 'the illness is old age itself'.

This belief was completely refuted by Galen (I3I-20I AD). He consolidated the Hippocratic and Aristotelian theories of ageing into one based on the humoral explanation of imbalance due to loss of heat. Old age brought about a dry and cold constitution of the body resulting from many years of life with a decline in organ function and a reduction in vitality and muscle strength. Galen considered that disease was contrary to nature, and as ageing was a natural and unavoidable process, it could not be considered pathological. However he did not believe it was completely healthy, but rather a state peculiar to itself, between health and illness; in this regard, he was certainly ahead of his time. ${ }^{12}$ Despite his teaching, including his theories of ageing which remained authoritative until the Renaissance, the view that old age was an illness remained prevalent in nonmedical literature. ${ }^{13}$

Although heat loss was inevitable, Galen believed the ageing process could be influenced and delayed by adopting a moderate lifestyle with attention to exercise and diet, which would promote warmth and moisture. $\mathrm{He}$ referred to this as 'the gerocomic art'. Parkin considers this to be the only form of geriatric medicine practised in the ancient world. ${ }^{14}$ Galen developed the concept of gerocomy, namely the care of the aged, in his treatise De Sanitate Tuenda ${ }^{15}$ and his fifth book on dietetics focused almost exclusively on the care of older people. ${ }^{7} 16 \mathrm{He}$ provided a detailed regimen for maintaining health, which remained influential for many centuries. However, older patients did not appear to be given special mention at this time and were considered as part of the adult group as a whole. Although there are many references in the medical literature of antiquity to the physical disabilities and symptoms associated with old age, there was no specialised focus on the medical care of older people. Parkin suggests that doctors' interests were limited to taking the age of the patient into account when making a diagnosis. Whatever level of interest ancient doctors took in their care of older patients, the observations derived from Greek doctors governed the medical treatment of older people for well over 1,000 years. ${ }^{12}$

\section{MIDDLE AGES AND RENAISSANCE (600-I800 AD)}

The Galenical system of medicine was consolidated within Islamic medicine by Ibn Sina (980-1037), also known as Avicenna, whose Canon of Medicine (c. 10I2) has been described as 'Galenic in its anatomy and Hippocratic in its theory'. ${ }^{17}$ Ibn Sina believed, as Galen did, that the result of ageing was a cold, dry body, stressing the predominance of the 'earthy element' which holds the parts of the body together into 'a compacted form' in those of 'decrepit age'. In his first book he devoted a section to a dietary regimen for older people, which would render the body warm and moist. He recommended that food should be taken in small amounts and that fruit, ginger and old, red wine were particularly beneficial. ${ }^{18}$

The idea of the existence of a place of eternal youth became embedded in Western thought throughout the Middle Ages, along with the search for the 'elixir of life'. It is illustrated in Roger Bacon's Cure of Old Age and Preservation of Youth, published in the thirteenth century. ${ }^{19}$ The work was the most important at that time to deal with the process of ageing, ways to 'remedy' it and to describe the clinical features of ageing, such as wrinkling of the skin and shortness of breath. ${ }^{13}$ Bacon believed that the life course could be extended to 150 years or more by living a life of moderation.

Interest in old age and ageing increased from the late Renaissance period into the sixteenth century, with numerous works relating to health and disease in old age appearing in printed form. Of those on ageing, the earliest of this period was Gabriele Zerbi's Gerontocomia 
in 1489, which revived Galen's concept of gerocomy. ${ }^{20,21}$ It concentrated on hygiene in older people, accepted that the diseases described could not be cured, and differentiated between natural death, as a result of the loss of innate heat, and death following illness. ${ }^{711}$ In his Opuscula Medica ( 1627), François Ranchin, of the University of Montpellier, also distinguished 'natural senescence', resulting from a lack of heat from 'accidental senescence', which was due to disease. ${ }^{7,22}$ Like Galen, he considered old age to be a condition between health and illness, one which was prone to disease. He made a plea that the medical needs of old people be taken more seriously:

Not only physicians, but everybody else attending old people... realise how noble and important, how serious and difficult, how useful and even indispensable is that part of practical Medicine called Gerocomica, which deals with the conservation of old people and the healing of their diseases... we get the impression not only that this noblest part of Medicine was not cultivated but even, yes, it has been flatly suppressed and buried."

One of the more remarkable works of the seventeenth century was Francis Bacon's History, Natural and Experimental, of Life and Death or of the Prolongation of Life, published in $1623 .{ }^{23} \mathrm{He}$ rejected Galen's humoral theory, countering it with a new concept of ageing based on 'spirit, or body pneumatical' through which the body functioned and which declined in old age as a result of unequal repair to different parts, so that eventually the whole body decayed, leading to natural death. However, he believed that life expectancy could be prolonged by pursuing a life of moderation. Among his list of instructions were: do not get excited; avoid the sun's rays; take baths; eat sweetened but not acid food; take physical exercise, but do not overdo it. ${ }^{10,13}$ Despite his influence in other areas and his reputation as a scientific thinker, his views on old age had little impact. ${ }^{10,11}$ In contrast, Medecina Gerocomica: Or the Galenic Art of Preserving Old Men's Healths, published in 1724 by Sir John Floyer of Lichfield (1649-1734), was considered influential by twentieth-century historians. ${ }^{24}$ Freeman suggested that it marked 'the beginning of modern geriatrics' and Grant regarded it as the first monograph to be printed initially in English on geriatrics. ${ }^{10,21}$ Although still based on the humoral theory, Floyer's text elaborated on the current state of medical knowledge of older people, suggesting many therapeutic remedies.

\section{EIGHTEENTH CENTURY}

The view that old age was itself an illness remained prevalent in the literature well into the eighteenth century, and for some physicians, as late as the twentieth century. In his doctoral thesis entitled That Senescence
Itself is an Illness, published in Germany in 1732, Jakob Hutter reflected the prevailing idea of the times, especially that of his more well-known teachers, Friedrich Hoffman and Hermann Boerhaave., ${ }^{7,25}$ Hutter's hypothesis had been proposed by a student of Boerhaave seventeen years previously, but Hutter provided a more detailed and systematic analysis. His theory of the ageing process postulated that there was a 'progressive hardening of all fibres of the body, which started from youth and resulted in obstruction to the blood supply. As a result of the weakened blood flow, stagnation led to 'fatal putrefaction'; thus old age caused death by direct means. Despite this, Hutter believed that the process could be modified and life prolonged by observing a 'correct' lifestyle, reflecting views that had been expressed previously by Galen and Francis Bacon. In a recent analysis, Schäfer stated that the importance of this theory lay in its emphasis on old age as a medical condition, which paved the way for the later development of geriatrics. ${ }^{7}$

Pathological studies later in the 1700 s, particularly those of Giovanni Morgagni, failed to confirm the widespread changes postulated by Hutter, and conversely, demonstrated the presence of local pathology in the majority of older people at post-mortem. By the late eighteenth century, it was generally accepted that death in most old people was due either to one illness or several with a cumulative effect and not a natural marasmus. ${ }^{26}$ Morgagni, in De Sedibus et Causis Morborum published in 176I, was sufficiently astute to point out in his study of anatomy and diseases that many diseases in old age, but especially chronic ones, can remain symptomless for many years. ${ }^{11,27}$ Two hundred years later this concept formed the basis of much clinical research on the unreported medical needs of older people. Benjamin Rush, an American physician, emphasised that old age was rarely the sole cause of death in his Account of the State of the Body and Mind in Old Age, with Observations on its Diseases and Remedies, published in the USA in 1793. ${ }^{28}$ According to Grant, his statement that 'Few persons appear to die of old age. Some of the diseases which have been mentioned generally cut the last thread of life' struck 'one of the last blows at the idea that old age is itself a disease'. ${ }^{10}$ However, it was another hundred years before the concept of 'old age infirmity' ended and Rosin wrote 'old-age infirmity is no illness'. ${ }^{26}$

\section{NINETEENTH CENTURY}

Research in age-related disease benefited from the advances in medicine made in France between the mideighteenth and mid-nineteenth centuries, but its innovative quality had deteriorated by the 1880 s. Much of it was based on pathological studies, relating the findings to clinical presentation where possible. One of 
the earlier, more perceptive studies was on pneumonia in 1835; Hourmann and Dechambre noted how disease could be present in older people, but exhibit few physical symptoms. ${ }^{29}$ Charles Durand-Fardel's practical treatise, Traité Clinique et Pratique des Maladies des Vieillards, published in 1854, has been referred to as both pioneering and a masterpiece. ${ }^{6,30,31}$ It covered the whole field of disease in old age, while attempting to link pathology with accurate diagnosis. Although Jean Martin Charcot enjoyed a higher profile in the field of medicine in old age, his Leçons Cliniques sur les Maladies des Vieillards, published in 1866, contained only two lectures specifically on old age and three on clinical thermometry in older people, while the remaining 16 were on rheumatism and gout. ${ }^{32} \mathrm{He}$ recognised that specific diseases existed in older people, such as osteomalacia and brain atrophy, that the 'gravest disorders manifest themselves by slightly marked symptoms' and that conditions occurring at any time of life 'present special characteristics' in later life. Charcot pioneered the use of the rectal thermometer as he was aware that peripheral temperature measurement did not reflect core temperature accurately in older people. In his first lecture of the series, he promoted the idea of a specialty: 'The importance of a special study of the diseases of old age cannot be contested at this day. ${ }^{33}$

France was the world leader in this area at the time. The basis for much of the research were the institutions known as 'hospices'. They were set up by royal edict in the mid-seventeenth century to serve a range of functions, including prisons, asylums for the insane and residential homes for older people. They were transformed into primarily medical institutions after the French Revolution of 1789. They were not reserved exclusively for older patients, but admitted those of all ages with chronic disability, including children. The Salpêtrière, which admitted only women, became the greatest single centre for geriatric research at that time partly because of its association with Charcot. Research also took place in Paris at the Bicêtre, which catered for men. From the early nineteenth century, the term 'gérocomie' had been in use in France to denote the specialisation in the diseases of old age. By the middle of the century, medical men working in the hospices called for the recognition of old age as a distinct period of life which required a specific approach and a special branch of medicine, 'médecine des vieillards', with its own training and therapy. These calls took place at a time when the practice of specialisation within medicine was firmly established in France and, by the end of the nineteenth century, had been introduced into the curriculum in the Paris Medical School. In the mid 1850s however, only $5-12 \%$ of physicians declared a specialty designation; the most common were surgical, namely general surgery, dentistry, obstetrics, orthopaedic surgery and ophthalmology, but psychiatry was also popular., ${ }^{5,34}$ By
1884 , the number of specialists had increased by $150 \%$ and the number of medical specialties expanded to include dermatology, venereology and neurology and sub-specialties such as gastroenterology, respiratory medicine and cardiology. ${ }^{35}$ Despite the existence of specialty hospitals for treating older people, geriatric medicine was not considered to be a recognised discipline. Weisz has suggested three possible reasons for this: the lack of specific therapeutic or diagnostic procedures; the inevitability and incurability of diseases of old age; and the fact that the elderly generated little public interest. ${ }^{34}$ In addition, research failed to progress, mainly because it had been pathologically based. Few therapeutic possibilities existed to manage disease in old age and physicians at that time did not interact with older patients to any great extent, as they only had contact with the small proportion who were admitted to the hospices. As medical interest in older people declined, geriatric medicine did not become a specialty in France until after 1950. ${ }^{6}$

However, interest in the ageing process and life expectancy was encouraged by the publication in 1882 of the theory of programmed death by August Weismann (1834-1914), a noted German evolutionary biologist. He proposed that animals were designed to have a limited lifespan; removing older members prevented overcrowding of the species. Death happened because 'wornout tissue' due to ageing could not be renewed indefinitely by cell division. The resulting decline in functional activity could lead to direct or so-called 'normal' death or indirect death due to reduced resistance to external influences. ${ }^{36}$ The theory was criticised mainly because few animals in natural populations died of old age and so ageing was not a significant contribution to mortality. With little experimental evidence to support it, Weismann's theory did not find general acceptance. ${ }^{37}$

Charcot's writings were translated and published in English in 1882 as Clinical Lectures on the Diseases of Old Age and had a considerable impact in Britain. ${ }^{33}$ The reason for this was no doubt the lack of papers on disease in old age in the English literature. One of the few was A Practical Treatise on the Diseases and Infirmities of Advanced Life, published in 1863 by Daniel Maclachlan, who was an attending physician to the Royal Hospital Chelsea. ${ }^{38} \mathrm{He}$ included dryness as well as wasting among the physiological changes of ageing, but did not accept that death resulted purely from age alone, pointing out that disease usually supervened to 'sever the cord'. He drew attention to the difficulty of diagnosis in older people where several diseases often coexisted. While Maclachlan suggested caution should be taken when prescribing drugs for older patients, those who were physically active benefited and tolerated 'active treatment'. However, modification of the dose was necessary in frailer patients as drug action became less 
certain as old age advanced. Digitalis in particular required to be administered with great care, but if done so, was 'a truly valuable medicine'. Maclachlan concluded by stating that the medicine of old age was an important branch of medical knowledge. ${ }^{38}$ The most notable publication of the nineteenth century was A Practical Treatise on the Domestic Management and Most Important Diseases of Advanced Life by George Day, professor of anatomy at St Andrews. In his book he complained that the diseases of old age had been neglected by physicians in the previous fifty years. ${ }^{39}$ The next significant English language publications on medicine and old age did not appear until the twentieth century in the USA, where the main advances in medical understanding of old age now originated."

\section{TWENTIETH CENTURY}

In 1909 Ignatz Leo Nascher (Figure I), a New York physician, published two papers on ageing and disease in the New York Medical Journal. In the first, he revived the idea that natural death could result from old age per se, due to decay of all the body's organs, with an accompanied 'diminishing nervous force to the point of cessation of nervous activity'. He concluded that the length of a person's life 'hinged on the mode of living' in which diet was the most important factor. ${ }^{40}$ In the second paper, he proposed the term 'geriatrics' for this specialty:

Geriatrics, from geras, old age, and iatrikos, relating to the physician, is a term I would suggest as an addition to our vocabulary to cover the same field, in old age, that is covered by the term 'paediatrics' in childhood. Senility is a distinct period of life having general features normal to it... it should be considered apart and distinct from maturity, and as a special branch of medicine. To such specialty I would apply the term geriatrics. $^{41}$

The term was chosen to reflect the growing specialty of paediatrics in the hope that the two would develop together. Nascher believed that diseases in old age were completely distinct from those of maturity and he developed his ideas over the next five years in over 30 articles and one book, entitled Geriatrics: The Diseases of Old Age and Their Treatment (for which he had some difficulty in finding a publisher). ${ }^{41} \mathrm{He}$ continued to struggle for general acceptance of geriatrics as a specialty. ${ }^{42}$

It is uncertain how Nascher became interested in the specialty he named; some suggest that it was based on his experiences of seeing how well older patients were treated during a visit to Vienna; or perhaps it was the result of his trip as a student to an almshouse where his instructor said a woman was suffering from old age for which nothing could be done. In his writing on other

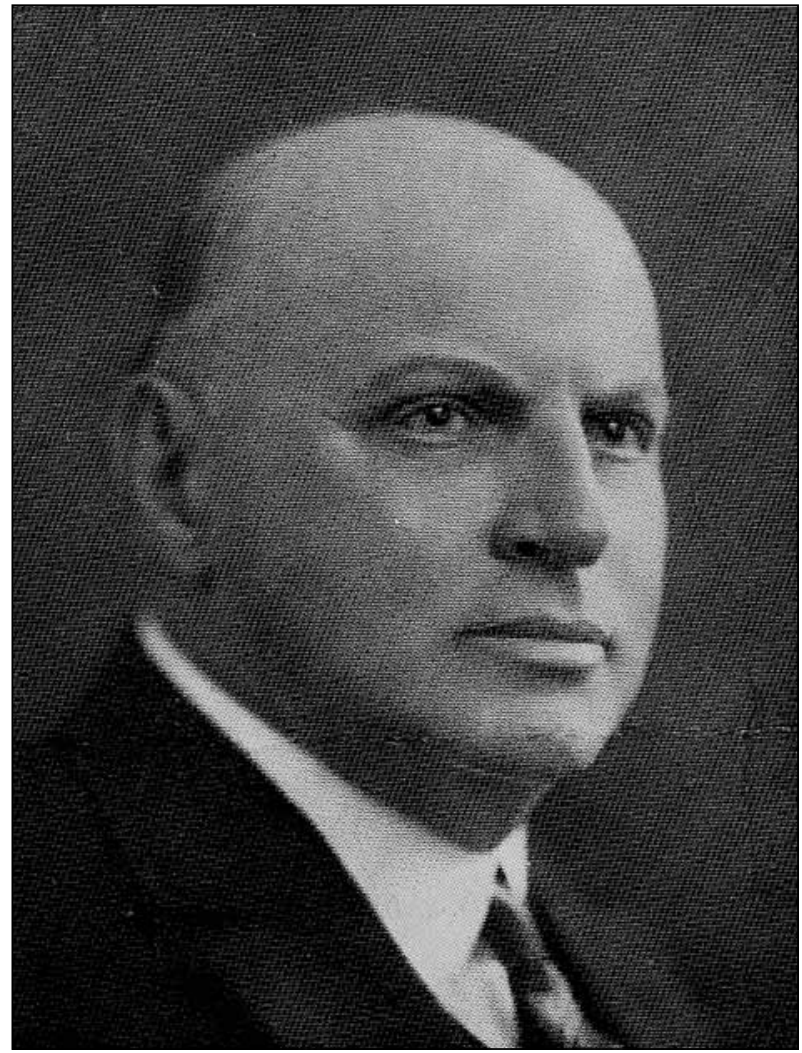

FIGURE I Ignatz Leo Nascher. Image courtesy of the Wellcome Library, London.

subjects he had shown sympathy for those who were underprivileged. In 1916 he was appointed physician to the New York Department of Public Welfare, later becoming Chief Physician at the city's Department of Hospitals. After his retirement, he took charge of the New York City Farm Colony, a poorhouse where inmates grew fruits and vegetables for themselves and residents of other city institutions. He aimed 'to change the antiquated methods of dealing with aged public dependents (that is, almshouse inmates) and rehabilitate them as far as possible physically and mentally'. ${ }^{1,43}$ Despite Nascher's initiatives, the practice of geriatric medicine did not progress in the USA until the development of services for older patients in the 1960s. ${ }^{44}$

The practice of geriatric medicine in Britain began in 1935 when Marjory Warren (Figure 2), deputy medical superintendent at the West Middlesex County Hospital, took over the care of several hundred mostly elderly and bed-bound patients in a former local workhouse. It had been usual for these patients to be ignored by the physicians responsible for their care, as they were felt to be incurable and uninteresting. The appalling conditions in the drab wards deterred many doctors from going back after their first visit but inspired Marjory Warren to action. She had the wards redecorated in stimulating colours with improved lighting, instituted rehabilitation as a team function and assessed all patients' state of 


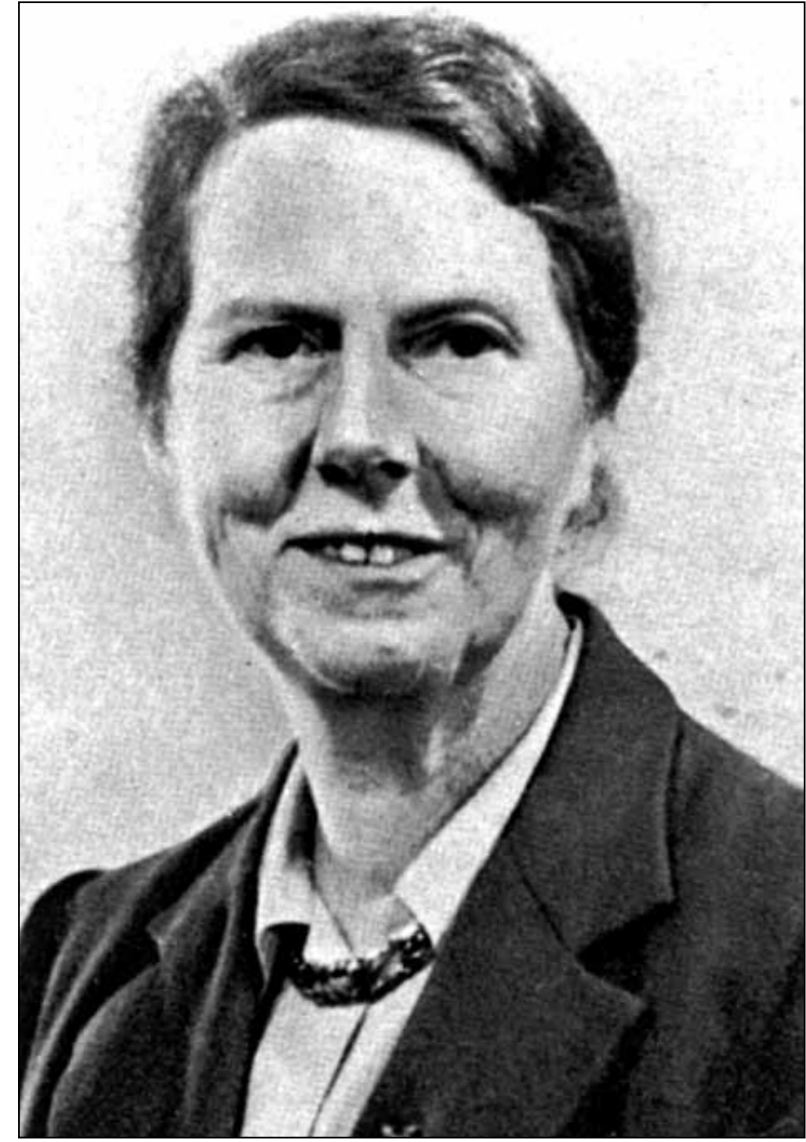

FIGURE I Dr Marjory Warren CBE, MRCS, LRCP (I8971960): the mother of British geriatric medicine. ${ }^{49}$ Copyright (2012) Royal Society of Medicine Press, UK

disability, identifying those who had potential for recovery, even if it was only to a limited degree. ${ }^{45}$ She promoted the establishment of geriatric units in order to protect the care of older people from medical neglect and called for the recognition of geriatric medicine as a specialty. Warren believed that 'until the subject [geriatrics] is recognised as a special branch of medicine in this country it will not receive the sympathy and attention it deserves'. ${ }^{46,47}$ That recognition took place in 1948 with the first appointment of a consultant geriatrician in Cornwall. ${ }^{48}$ Thus began the development of modern geriatric medicine as a specialty in the UK born out of a humanitarian concern for chronically sick older people.

\section{CONCLUSION}

Ageing has been defined recently as a progressive, generalised impairment of function resulting in a loss of adaptive response to stress and in a growing risk of agerelated disease, the loss of adaptability giving rise to increased frailty and the probability of death. ${ }^{37}$ This concept can be seen in the theory of ageing proposed in the Hippocratic Corpus, in Aristotle's writing in Classical Greece and in the work of the American physician Benjamin Rush, in the late eighteenth century. The reduced rise in body temperature in response to infection with increasing age was known to the Hippocratic authors when they stated that fevers were not so acute in old people, although we now know that this is the result of a decline in the immune system. That the presentation of disease can be different in older patients and that pathology can be asympomatic was noted by several authors, including Morgagni and Charcot, as well as Hourman and Dechambre in their study on pneumonia in nineteenth-century Paris. In the mid-nineteenth century Maclachlan recognised the importance of co-morbidity in older people and the altered response to drug therapy. The majority of the early theories of ageing were based on the humoral theory of disease, and their proponents, from Aristotle, Galen and Avicenna to Roger and Francis Bacon, were convinced that the ageing process, although inevitable, could be delayed.Their suggested remedies of a moderate lifestyle with attention to healthier food and adequate exercise are still widespread today. 


\section{REFERENCES}

I Morley JE. A brief history of geriatrics. J Gerontol A Biol Sci Med Sci 2004; 59: I I32-52. http://dx.doi.org/10.1093/gerona/59.II.II32

2 Evans JG. Geriatric medicine: a brief history. BMJ 1997; 315:10757. http://dx.doi.org/I0.1 I36/bmj.315.7II5.1075

3 Barton A, Mulley G. History of the development of geriatric medicine in the UK. Postgrad Med J 2003; 79:229-34. http://dx.doi. org/I0.II36/pmj.79.930.229

4 Thane P. Old age in English history: past experiences, present issues. Oxford: Oxford University Press; 2000.

5 Ackerknecht EH. Medicine at the Paris Hospital 1794-I848. Baltimore:The Johns Hopkins Press; 1967.

6 Stearns PN. Old age in European society. The case of France. London Croom Helm; 1977.

7 Schäfer D. 'That senescence itself is an illness': a transitional medical concept of age and ageing in the eighteenth century. Med Hist 2002; 46:525-48.

8 Lloyd GER, editor. Hippocratic writings. London: Penguin; 1978.

9 Kirkwood TB, Ritter MA. The interface between ageing and health in man. Age Ageing 1997; 26:9-14. http://dx.doi.org//0.1093/ageing/26. suppl_4.9

10 Grant RL. Concepts of aging: an historical review. Perspect Biol Med 1963; 6:443-78.

II Thane P. Geriatrics. In: Bynum WF, Porter R, editors. Companion encyclopaedia of the history of medicine. London and New York: Routledge; 1993.

12 Parkin TG. Old age in the Roman world. A cultural and social history. Baltimore and London:The Johns Hopkins University Press: 2003.

13 Minois G. History of old age. From Antiquity to Renaissance. Cambridge and Oxford: Polity Press; 1989.

14 Parkin T. The Ancient Greek and Roman worlds. In:Thane P, editor The long history of old age. London:Thames and Hudson; 2005.

15 Galen C. De sanitate tuenda. Paris: G Rubeums; 1517.

16 Galen C. On the properties of foodstuffs. Edited and translated by Powell O. Cambridge: Cambridge University Press; 2007.

17 Gruner OC. A treatise on the canon of medicine of Avicenna. New York:Augustus M Kelly; 1970.

18 Freeman JT. Medical perspectives in aging. In: Gruman GJ, editor. Roots of modern gerontology and geriatrics. New York:Arno Press; 1979.

19 Bacon R, Arrais DM, Browne R. The cure of old age and preservation of youth. London:Tho. Flesher and Edward Evets; 1683.

20 Zerbi G. Gerontocomia. Rome: Eucharius Silber; 1489.

2I Freeman JT. The history of geriatrics. In: Gruman GJ, editor. Roots of modern gerontology and geriatrics. New York:Arno Press; 1979.

22 Ranchin F. Opuscula medica. Lyons: Pierre Rabaud; 1627.

23 Bacon F. History of life and death. London: M Lownes; 1623.

24 Floyer J. Medicina gerocomica: or the Galenic art of preserving old men's healths. London: J Isted; 1724.

25 Hutter J. [That senescence itself is an illness.] [Thesis]. Germany: University of Halle; I732. German.

26 Kondratowitz $\mathrm{HJ}$ von. The medicalisation of old age. In: Pelling M, Smith RM, editors. Life, death and the elderly: historical perspectives. London and New York: Routledge; I99I.
27 Morgagni G. On the seats and causes of diseases investigated by anatomy; in five books, translated from the Latin by Benjamin Alexander. London: Johnson and Payne; 1769.

28 Rush B. An account of the state of the body and mind in old age. Medical Inquiries and Observations 1793; 293-321.

29 Hourmann AJ, Dechambre A. [Clinical history for use in diseases of the aged: made at the Salpêtrière.] Paris: Migneret; I835. French.

30 Zeman FD. Life's later years. Studies in the medical history of old age. In: Gruman GJ, editor. Roots of modern gerontology and geriatrics. New York: Arno Press; 1979.

31 Durand-Fardel M. [Clinical and practical treatment of diseases of the aged.] Paris: Germer Bailliere; 1854. French.

32 Charcot JM. [Clinical lectures on the diseases of old age.] Paris: A Delahaye; 1866. French.

33 Charcot JM, translated by Hunt LH. Clinical lectures on the diseases of old age. London: Sampson Low, Marston, Searle and Rivington; I882.

34 Weisz G. Divide and conquer. A comparative history of medical specialisation. Oxford: Oxford University Press; 2006

35 Weisz G. Mapping medical specialization in Paris in the nineteenth and twentieth centuries. Soc Hist Med 1994; 7:177-21I. http:// dx.doi.org/I0.1093/shm/7.2.177

36 Weisman A. Essays upon heredity and kindred biological problems, Volume I. Oxford: Clarendon Press; 1889.

37 Kirkwood TB. The evolution of ageing. Mech Ageing Dev 2002; 123:737-45. http://dx.doi.org/10.1016/S0047-6374(0I)004I9-5

38 Maclachlan D. A practical treatise on the diseases and infirmities of advanced life. London: John Churchill and Sons; 1863.

39 Day GE. A practical treatise on the domestic management and most important diseases of advanced life. Philadelphia: Lea and Blanchard; 1848.

40 Nascher JL. Longevity and rejuvenescence. NY Med J 1909;89:795800.

4I Nascher JL. Geriatrics. NY Med J 1909; 90:358-9.

42 Freeman JT. Nascher: excerpts from his life, letters and works. In: Gruman GJ, editor. Roots of modern gerontology and geriatrics. New York: Arno Press; 1979.

43 Barker WH. Geriatrics in North America. In: Tallis RC, Fillit HM, editors. Brocklehurst's textbook of geriatric medicine and gerontology. 6th edition. London and Philadelphia: Churchill Livingstone; 2003.

44 Forciea MA. History of geriatric medicine. In: Pignolo RT, Crane MK, Forciea MA, editors. Classic papers in geriatric medicine with current commentaries. Totowa, NJ: Humana Press; 2008. http:// dx.doi.org// 0.1007/978-I-59745-428-5 2

45 Warren MW. Care of the chronic aged sick. Lancet 1946; I:84I-3. http://dx.doi.org/10.1016/S0140-6736(46)91633-9

46 Warren MW. Care of chronic sick. Br Med J 1943; 2:822-3. http:// dx.doi.org/I0.I I36/bmj.2.4329.822

47 Warren MW. Rehabilitation of the elderly patient. Ann Phys Med 1960; 5: |70-81.

48 Brocklehurst JC. Dunn RB, Duursma SA. Geriatric medicine: history and current practice in Europe. In: Tallis RC, Fillit HM, editors. Brocklehurst's textbook of geriatric medicine and gerontology. 6th edition. London and Philadelphia: Churchill Livingstone; 2003.

49 MJ Denham. Dr Marjory Warren CBE MRCS LRCP (1897-1960): the mother of British geriatric medicine.J Med Biogr 201 I; 19:105I I0. http://dx.doi.org//0.1258/jmb.2010.010030 